\title{
Integration of Unequal Units: Comparing the German and the European Unification Processes
}

\author{
Anne Sophie Krossa
}

\section{Introduction}

More than fifteen years after the beginning of the so-called post-communist period in East Central Europe specific problems of the multidimensional changes are discussed with increasing frankness. The importance of topics such as conflicting interests and different identities continues to grow. This is the case in both Germany and the European Union (EU) both frames for the integration of their Eastern and Western parts

In both cases we can find a basic structure of centre and periphery, which partly reproduces itself on different levels. In a traditional sense, the West plays the part of the centre while the East represents the periphery. This study focuses on the latter. Centre-periphery structures symbolize differences, such as quantitative and qualitative asymmetry. If relations are perceived as correlating systematically with asymmetrical structures, feelings of discontent and reactions of protest and resistance may be favoured in peripheries. Specific forms of identity are then likely to become more characteristic than others. The internal functions and external consequences - especially for the entire system, which includes all parts of the structure - shall be analysed.

My approach is based on the differentiation between the 'specific' and 'diffuse' support for political systems according to Easton (1965). Common features of integration processes within Germany on the one hand, and Europe on the other hand, as well as differences between them will be illustrated. A detailed elaboration of the German-German integration serves as a contrast for the situation of the East Central European Countries within the EU. The analysis of the European process focuses on Poland by way of example. The conclusion concentrates on the importance of the different types of support in the context of collective identity-construction concerning the chosen cases as well as hierarchic structures in general.

\section{Theoretical background}

Easton (1965) argues that while specific support for a system is based on a concrete satisfactory output - of a political kind which can materialise economically - diffuse support is independent of outputs. ${ }^{1}$ It can be rooted in generally shared interests, loyalty, solidarity and legitimacy, is an approval of the system in itself and shows analogies to the concept of identity. In this context, it is necessary to take into consideration the fact that in GermanGerman relations as well as in the European East-Western relations we do not only find a whole system ('Germany' or 'European Union'), but many subsystems too.'

Easton's approach can be applied if an inter-societal, rather than an intra-societal, situation within a shared system is assumed. ${ }^{3}$ However, modifying this theory has a condition: both partners, the stronger and the weaker one ${ }^{4}$, have to be clearly interested in integration so that a certain common and simultaneously superordinated systemic constraint exists. In both cases this can be assumed as given. 
As aspects of identity are focused; this text mainly refers to diffuse support. One important supposition is: the greater diffuse support for a system, the lower its dependence on specific support and vice versa. If the system as a whole has a relevant advance of trust at its disposal, the political output of the stronger partner or the material help respectively may be, at least for some time, lower, compared to its dimensions in a situation with hardly any or even no diffuse support. However, it has to be assumed that diffuse support cannot be stable in a long term perspective if specific support was not perceived as sufficient. In other words, if interests are not satisfied to a certain degree, it is possible that the belief in the legitimacy of a situation or relation will decrease. This can withdraw the basis of loyalty and solidarity. But it is not imperative that the interests are of a material kind, rather perceptions of status are focused. ${ }^{5}$

\section{The Unification Processes 'East' - 'West' Germany and 'East Central Europe' - ‘European Union': Similarities and Differences}

At their beginning, both unification processes were based on relatively widespread diffuse support. ${ }^{6}$ This was substantiated by elements of collective identity ${ }^{7}$. In the case of Germany there existed a very widespread traditional idea of unity, which can take different shapes, depending on generation especially, and in the European context a conscience of belonging together in principle can also be found. The two cases are most comparable on a structural level. Differences can be analysed with the help of the specific ways in which the Eastern and Western parts approach each other. These concern speed, geographic location and size.

European unification is certainly more extensive and complex because of relatively highly differing degrees of development. From a West European perspective the geographic space, that is 'entitled' to experience loyalty, is relatively harder to define. This is one of the reasons why the European perception of unity was far more asymmetric than in the German-German example (see footnote 6). However, in both cases the citizens of the Eastern regions felt a stronger tie with the West than the other way round. In addition to this pull-factor, the European example shows the important push-factor of an aimed demarcation towards Russia. $^{8}$

The question of German reunification found a fast positive answer, albeit without leaving much room for discussion. Correspondingly, the speed of equipping East Germany institutionally and infrastructurally was high and a shared identity seemed to be rather selfevident. This was favoured by the assumption that cum grano salis regional identity is less suitable for instrumentalising a scheme of 'friend and enemy' as national identity, mainly because of the lower number of options for distinction (Bergem 1999: 199). Altogether, the starting-conditions of the German case may be called relatively favourable.

After the initial euphoria, both Eastern regions soon experienced disappointment and disillusion'. Disappointed expectations became externalized which meant that deficits of the transformation processes were often not ascribed to the failure of state-socialism but to the partner of unification (Woderich 2000: 104). This is reinforced by persisting differences between East and West, which are often perceived, as directed 'from above'. Additionally, these differences, may they be the unequal payment in East and West Germany ${ }^{10}$, the interim regulations for free exchange of persons from East Central to Western Europe ${ }^{11}$ or the argument about subventions in the field of agriculture ${ }^{12}$ are felt by a large proportion of the population.

Forms of identity which develop are also increasingly directed against the perceived dominant partner. Dysfunctional consequences for the system as a whole are then inevitable. However, the course of transformation makes these identity-types seemingly unavoidable because the formal inclusion into the new institutional system makes the exclusion of culture and way of life rather probable. This results in feelings of being a second class-citizen or stranger in one's own country (Woderich 1996: 87f.). But these identities are not a direct reproduction of old patterns. Rather, they are new forms of specific self-view which combine 
forms of praxis which people already are accustomed to with current experiences and future prospects (Woderich 1996: 96). This has specific consequences for each system as a whole.

\section{The German Unification}

As has been mentioned already, in general, the starting conditions of the German unification were more favourable. This refers to a stronger and, at least in the beginning, a far more symmetrical feeling shared unity and identity. However, on closer inspection it is possible to detect that the feeling of belonging together, loyalty or solidarity has partly given way to rather pessimistic attitudes ${ }^{13}$. A majority of East Germans do not perceive themselves as treated equally, thus regionally different identities gain importance ${ }^{14}$.

\subsection{From euphoria to disillusion}

In East Germany the situation developed as follows: after a euphoric phase, which was characterized by a considerable lead of diffuse support, it soon became obvious that bringing the systems into line with each other economically would prove difficult - at least in the short to medium term. The actual problematic structural conditions of East Germany appeared to fade into the background while the West was increasingly blamed for providing insufficient support and responsible for the difficult economic situation in the East. This perception of the Western output favoured the development of low, specific support on the part of the East. At the same time, a specific interpretation emerged that suggested that the West had no sufficient feeling or understanding of solidarity; in other words, it did not invest enough diffuse support in the common project. Therefore the basis of diffuse solidarity of the East was reduced.

At the beginning, this process was primarily about economic issues. The perception of a poor and inadequate political integration completes this picture. For the individual, this is expressed as a feeling of being 'absorbed' or 'annexed', as being inferior in a one-sided process of assimilation, because important political questions are decided 'elsewhere'. ${ }^{15}$ The existing feeling of strangeness towards the (Western) political system is grounded in the fact that the East Germans fought successfully to take over the democratic institutions but, however, did not ascribe the practical process of institutional transfer to themselves (Woderich 2000: 106). It appeared to be an application of external institutions and their 'players'. This, combined with the impression of a 'simulated' rather than actually practiced democracy, favoured a loss of diffuse support ${ }^{16}$. As many East Germans viewed their (political) interests as being unconsidered, they then appeared to question the legitimacy of the system as a whole, which also diminished feelings of loyalty and solidarity.

In light of this, the multidimensional structure of centre and periphery which is related to economic as well as to political interests, became identity-effective. This emphasises how sensitive the relation between diffuse and specific support is. Therefore, both ideal-types can only be separated analytically, because in reality they are not independent of each other. Instead, they stand in a relation of exchange, especially concerning aspects of status.

\subsection{The development of an Eastern 'counter-identity'}

There have been attempts to reinterpret this perceived multidimensional inferiority. These include a symbolic reference to objects, codes and signs that can create a sense of connection, and relate to a shared world and its specific history, as well as to generate an exclusive knowledge of the (East German) minority, thus converting the structural inferiority into a virtual superiority (Woderich 2000: 109). This is expressed for example by preferences which have exclusive meanings. Discourses about assimilation to West German forms supported a consciousness and an emphasis of East German markers as a counter-identity (Bafoil 1995: 5). 
The consciousness of an East-identity emerged in many and diverse forms. This has also an exclusive dimension because of its characteristic particularism: a demarcation from Western Germany which might have problematic consequences for the joint project 'Germany today' and its important functions and expectations on both sides ${ }^{17}$. 'Obstinate formations of identity ${ }^{\prime 18}$ therefore try to restabilise specific traditions as a typical reaction to radical systemic discontinuities - largely independent of their democratic legitimation (Woderich 2000: 112).

Reactions of the West include attempts to understand, but also helplessness, a simple lack of interest and a refusal to accept responsibility for problematic aspects of the integration process. At least indirectly, the East is reproached with a lack of its own initiative and its incapability of effectively handling the means at its disposal. Primarily, this is about financial help that has been and continues to be transferred from West to East Germany ${ }^{19}$.

The West is significantly less conscious of political asymmetries. This is not so surprising because, structurally, it is the stronger part. Widespread reactions can only be observed in the context of electoral successes of the socialists (former communists) in the East. In general, the West also developed a regional self-concept which distinguishes itself from the so-called 'Ossi', though this obviously has passed its zenith already ${ }^{20}$. Thus, an asymmetry exists on the level of identity: the West does not need the East for positioning itself; rather it is the other way round ${ }^{21}$.

\subsection{Structures of identity in today's Germany}

As the structure of centre and periphery can be perceived as relevant to both East and West Germany and runs along several levels, it is difficult to fully comprehend. For example, when cleavages are fixed on the level of identity, then the situation has the potential to influence society as a whole. Stabilization of elements of identity with a mainly exclusive character might, however, be problematic for shared systems.

This situation includes the risk of switching from the level of politically negotiable interestdiscourses to their 'culturalization'. Individual opinions then become an expression of a cultural character with a tendency of being deeply rooted and hardly changeable (Bergem 1999: 200). Consequently, the policies are thrust into the background because of their supposed ineffectiveness.

This risk grows if specific East-German experiences are not considered in public discourses and, therefore, the specific ways of understanding and life-achievements are not recognized (Woderich 1996: 96). The longer this problematic situation lasts, the stronger the wish and the need of articulation of 'East-German problems' becomes.

\section{The process of unification between 'East Central Europe' and the 'European Union'}

There are several reasons for choosing the relations between the European Union and Poland as an example of integration between West and East Central European countries. Firstly, aspects of the typical regional course of history have developed especially clear contours in Poland. Historical consciousness is still exceptionally strong there (from a Western, and especially from a German perspective). In addition, the current conflicts between Poland and the EU manifest themselves with particular distinctiveness to the key debates of this article.

I begin with a glance at Polish-European history which provides the basis for the Polish attachment to (Western) Europe and therefore forms the background to the advanced diffuse support for the shared institutional system of the 'European Union'. 
The sense of belonging to (Western) Europe has genuine religious roots: "In the beginning of the 'Europeanisation' of Poland stands the adoption of Christianity from Rome in the year 996" (Krasnodebski 1999: 77, translated quotation). Poland's position as a 'religious border' manifested itself historically as antemurale christianitatis and traditionally plays a particular role in understanding the nation. In Poland a close relationship between Catholic faith and national distinction from 'the outside', mainly the non-Catholic 'barbarism', symbolized by Russia, existed. At the same time, religion played a functional role by orientating identity towards Western Europe. Hence, it was an important aspect of an open-mindedness concerning the values and way of life of Western Europe at that time and supported their adoption in Poland. Even today, Christianity has an important meaning as a criterion for cultural-geographical demarcation and as a spring for shared values from an East Central European and especially from a Polish perspective (Klunkert 1996: 234).

This leads to a second relevant traditional line of identity construction involving the analysis of historical developments, namely, the liberal elements of self-understanding, as well as related forms of collective identity. Historically, the roots of this line of tradition in Poland reach back to the 'Republic of Nobility' in the $16^{\text {th }}$ century. At that time, an early democratisation of the state took place (Stölting 1995: 159f). The Polish situation in those days was characterised by the social power in the hands of the nobility that made decisions through an early kind of parliament. This period has since been known as the golden freedom. This is the background for the employment of the term 'Pole' in a political sense especially in the $17^{\text {th }}$ century (Krasnodebski 1999: 93). Additionally, these ideologies became concrete in the first written constitution of modern Europe that was passed by the Polish Imperial Diet on May $3^{\text {rd }} 1791 .{ }^{22}$

At that time, thanks to the fundamental influence of the French Revolution, nationalism was used to support the creation of politcial entities, in the form of the nation-state. Throughout $18^{\text {th }}$ and $19^{\text {th }}$ century Europe, nationalism was classified as an ideology of liberation in a selective and inclusive sense. 'Europe' and 'civil freedom' became weighty slogans. A connection of the national ethos with internationalist and generally humanistic ideals characterised Poland at the beginning of the $19^{\text {th }}$ Century. ${ }^{23}$

Europe had a particular position when actions in the context of conflicts were interpreted not only in the name of national particularism, but also for the 'freedom of Europe'. The idea of the democratic constitutional state and the general acceptance of human rights were the most striking features of the historic images of Europe (Klunkert 1996: 235). The political and inclusive character of the corresponding collective identity with its emphasis on the individual (vs. the collective) favoured a kind of liberal patriotism instead of exclusive nationalism.

Paradoxically, at the same time a national mythologisation of history took place. ${ }^{24}$ This means, that the liberal element also offered a possibility for identifying cultural - and collective aspects of national identity as natural ones. The reciprocal chance of connecting the analytically antithetical categories in this way offers the theoretical basis for the amalgamation of the different identity elements. Although it is questionable about whether it is appropriate to speak of a fracture on the depicted background of the numerous possible connections and real combinations, this is essentially what happened, with an historical fracture taking place extending once more the multidimensionality of collective identity in Poland. After the primarily liberal political nationalism the tables had turned again.

The divisions of Poland in 1772, 1791 and 1795 played a decisive role in this process. ${ }^{25}$ After the last division the Poles lost the right to exist as a state. On the basis of the long-standing situation of foreign rule in combination with a weak bourgeoisie, the exclusive national element became accentuated at cost of liberal elements. Correspondingly, the former central reference point of national unity - civic rights and liberal freedom - underwent a substantial transformation: romantic ideas of 'common blood', 'common descent' and shared language resulted in the development of an exclusive nationalism (Weiss/Reinprecht 1998: 29). This was a turning-point, which shifted the importance of national identity from humanism to an exclusive perspective. ${ }^{26}$ 
Like most of the post-communist states Poland was not able to return to real experiences of democracy. This was also true for the interwar period: "The so-called democratic experiments of the interwar period lasted less than a decade and are best understood, in any case, as authoritarian politics in democratic guise" (Bunce 1995: 89) ${ }^{27}$. During this time, the traditional line of identity construction against the East, and primarily in opposition to Russia, was revived. Again, the concept of Poland as an outpost of Europe dominated. This time, the demarcation was less religious and more political - although it certainly followed the same borderlines. The Polish border to the East was considered as being identical with the imagined border of a European identity (Holzer 1996: 88).

The Second World War affected Poland in a particularly hard way. The population found itself again under foreign rule, this time by the German Nazis. Not surprisingly, an exclusive national identity was typical for the Polish population until the end of the Second World War.

Poland didn't become a sovereign state after 1945. The communist system was perceived to be forced upon the Polish people and as extraneous to the 'Polish nature': "From a traditional Polish point of view, bolshevism was a product of a civilising crisis and an extreme expression of authoritarian tendencies within the Russian culture. Therefore it sometimes has been even regarded as 'asiatic barbarism'" (Krasnodebski 1999: 74, translated quotation).

Although a 'selectively excluding nationalism' was tolerated from 'above' after 1945, this did not help to establish a real identification between the Polish people and their rulers, because exclusion was mostly aimed at the non-socialist West. The new rulers understood that a limited synthesis of communism and exclusive nationalism was politically expedient, thus rendering it possible to appear as guardians of the historical interests of the nation (FischerGalati 1994: 34). In doing so, traditional nationalist concepts were revived, such as "the superiority of a mono-national state over a multinational one and the conviction that the state consisted of a 'racially pure' Polish population" (Holzer 1991: 400, translated quotation). Furthermore, anti-German emotions as well as a 'tactical anti-Semitism' were instrumentalised, while Russia and the Russians, who traditionally have been a target of exclusive nationalistic resentments from the Polish side, served as a 'natural reserve' (Holzer 1991: 400). This concept obviously came into conflict with the traditional lines of identity construction, and therefore did not really support identification with the situation and the system. However, a partial success of this strategy could have been observed.

At the same time, another ideology developed, which can be considered a counterpart: a mythological and 'complete' structure of a moralistic image of the society (Tatur 1994: 28). In this sense, 'European identity', mainly as a 'Central European identity', gained more attention, especially in the 1980s.

Historically the relation to Western Europe is typically linked with a specific mysticism. This emphasises religious ideology, as well as the one of enlightenment and favours the idea of a quasi-natural feeling of unity which forms a basis of diffuse support.

\subsection{Images of Europe and of the European Union in Poland after 1989}

The images of Europe and the EU are closely linked. Immediately after 1989 the perception of the two as one concept was very common. Today the distinction between European identity and support for European integration within the EU framework is more clear-cut.

\subsubsection{Radical Change and Euphoria}

While 'Europe' symbolises a shared culture, the EU represents its contemporary institutional composition. In principle, 'Europe' for the East Central European side functions largely as a 'moral justification' for the right to participate in the EU. During and shortly after the upheaval 
of 1989, this differentiation between the two terms was not that distinct. On the contrary, the EU was perceived as heir of an old, positively revitalised Polish 'European identity' and therefore was able to set an 'advance of trust'.

The EU has been seen as the (then) present-day shape of Europe. In this sense, it had substantial symbolic value: "The EU has been an important external anchor to the consolidation of democracy since a civic, democratic ethos has been inherently linked to European identity" (Villa Faber Group 2001: 37).

Alongside economic and political interests, a traditional element of identity was also highly significant. Although the interests in the foreground were mostly of material kind, the expectation, or better, the pretence that Western Europe should come up to these interests was mainly based on the symbolic level of the historical and cultural self-understanding of the post-socialist countries of East Central Europe. Part of this was, and still is, based on the claim of historical and cultural 'belonging' to Europe, which "had been violently interrupted for 40 years" (Srubar 1995: 679, translated quotation).

The deep roots of European identity were indicated by the self-denotation as (being part of) 'Central Europe' and by the claim of 'returning to Europe'. These sentiments were frequently expressed during this phase in Poland and emphasised the wish to become a member of the EU. At the beginning of the collapse of the real-socialist regime, unrealistic concepts and images of Europe were widespread. They were additionally pushed by a feeling of threat as a neighbour of Russia. At this time, a psychological repression concerning the past of realsocialism also began. But as the political reality in Europe had changed substantially, the 'frozen' pre-war images of Europe could not be applied anymore (Klunkert 1996: 236).

Holzer (1996: 91) states that the image of Europe in Poland during the first half of the 1990's was mainly determined by economic factors, especially because most of the knowledge was obtained through satellite-television; impressions and pictures of prosperity were perceived as European characteristics. The term 'Europeanization' for a majority symbolised the rise of the living-standards, high wages, quality of life, cleanness and order as well as a high level of technology and work organisation (Holzer 1996: 97).

For more educated parts of Polish society, the cultural factor - an 'old European culture' was, and is, assumed to be more important. These political and intellectual circles interpreted 'Europeanization' as the process of economic integration into the EU on the one hand and the "development of shared European norms of political and civil life (political democracy, human rights, self-administration, rule of law) on the other" (Holzer 1996: 97, translated quotation). The more unrealistic and especially unbalanced the images, expectations and hopes were, the more inevitable have been disappointments.

\subsubsection{Changing images of Europe and the European Union}

As the misperception of the new situation became obvious, the interpretation of the interconnection between 'Europe' and 'European Union' began to unravel. European identity was more and more understood as not necessarily connected with personal support for EU integration.

The first implementation of new institutions to foster European integration, along with underlying values, was based on a widespread and diffuse support (Easton 1965). This support lost ground when the economic and the political output of the new common system (the EU) fell far below the expectations and was interpreted as inadequate support of 'the other side'. 'Insufficient' output withdrew the basis from potentially ongoing diffuse support. This manifested the differentiation between a 'cultural Europe' and an 'economic EU'.

In the economic field, disillusionment was representative of disappointed consumer expectations as well as psychological stress related to issues such as personal job insecurity. 
This mainly concerned workers and employees of state-owned enterprises, a large number of smallholders and pensioners. At the political level, the country saw itself confronted with problematic home affairs such as corruption and the need to overcome the political crimes of the communist period.

This preparation process from the side of the new members in East Central Europe meanwhile was considered largely as a unilateral adaptation to the Western European rules. The asymmetrical structure of the access negotiations turned out to be more and more problematic. The East Central Europeans expected equal negotiation in principle, but instead had to accept that their level of access is granted by the West. Critics became louder when the negotiations were perceived as intergovernmental and 'our' (i.e. 'Polish') national interest had to be defended against the national interests of the incumbent EU member states (Villa Faber Group 2001: 1). Two examples illustrate these problems: the negotiation of the constitutional convent and agricultural policy.

Although the new member state countries are directly affected by the results of the discussion about the future shape of the EU, during negotiations they were present as observers only. Being reduced to this status, however, was a source of ongoing disappointment that was easily connected to the already existing scepticism concerning the process of accession. Because of the impression that the EU doesn't attribute adequate meaning to their positions, there was a significant risk that the East Central Europeans would lose interest in the future of the EU (Villa Faber Group 2001: 50) or that they would feel provoked and try to enforce their specific national positions.

The agricultural policy is especially problematic with regard to the East Central European countries. ${ }^{28}$ Poland still has a large number of smallholders. On the one hand this means that if the EU would treat the Western and the Eastern peasants equally, it would create immense costs for the Union and additionally confuse the entire income relation. On the other hand, the now decided rejection of equal treatment and the decision to adopt transitional regulations for years, affects huge parts of the population. The political weight of smallholders in Polish society is big enough to provoke crises and shifts in public opinion ${ }^{29}$. At the same time, there is a growing impression of being politically and economically powerless within the 'common system', particularly among political circles in Poland. These circles already anticipate that Poland may play only a secondary role in the process of European integration (Holzer 1996: 101). The wider population also feels powerless face to face with the EU. ${ }^{30}$ Klunkert (1996: 238) writes: "This self-observation as being 'Europe's edge' stands in crass opposition to the self-perception as 'Europe's centre', as the historical images of Europe suggest the position of the own culture".

Summing up, it can be said that the perception of the EU as non-transparent, undemocratic and therefore illegitimate, increases. The relative turning off from Western Europe intensified when Russia, as a significant push-factor, lost importance as security interests decreased because of the accession to NATO of Poland, Hungary and the Czech Republic.

This opened the way from euphoria and the development of trust to scepticism. Consequently, it became more and more difficult for governing elites to handle the divergence between meeting the requirements of the Union and convincing their population of the necessity and value of the concessions - and possibly ensuring it morally through a 'European community of values' ${ }^{\prime 31}$.

\subsubsection{Poland after the EU Accession Referendum}

Poland is the biggest country of the East Central European region. Today it is characterized by huge agricultural and obsolete industrial sectors which pose serious problems to the necessary processes of structural modernization. This situation is the basis of widespread calls for welfare payments and 'careful' restructuring. Attitudes towards the European Union are quite mixed. Until a few weeks before the referendum took place on 7-8 June 2003, large parts 
of the population were sceptic and perceived European integration as a dominating menace. The committee responsible for the referendum campaign feared a defeat with incalculable societal consequences and, therefore, reacted to these conditions by appealing to a European consciousness. This meant that they used an emotional and direct identity related argument. For this purpose, Poland typically was called not only 'part of Europe' but 'being Europe'.

This strategy was successful: more than $50 \%$ participated in the voting and more than $80 \%$ voted 'yes'. However, enormous expectations were raised leading to the view that a much better future will follow the accession to the European Union. This combination is not without risks. It links identity-aspects relatively closely with a combination of immaterial and material elements, united in the expectation of a better future. Now, the strategy of the campaign committee is to say, "Yes, our situation will improve in an integrated European Union, if we work hard on it". The open question is, "has this been achieved in time or is a new wave of disappointment is already on its way?'

\subsubsection{Steps of Development Towards an Antagonism Between 'EU' and 'Nation'}

If support for a 'common Europe' in Poland should decrease further, antagonisms between 'Europe' and 'the Polish nation' will grow. Indeed, this can already be observed. This development is related to the traditional East Central European understanding of 'nation'. As previously shown, after long periods of foreign rule, the nation is interpreted as the essence of the collective self, including the wish for significant independence as a political subject. If political output is sensed as unsatisfactory due to minimal autonomy and participation, it leads to refusal of an 'EU-hegemony'. Concerning Europe-related aspects of identity, this means that "the more frequently conflicts concerning objectives occur between the European and the national level, the higher the probability of an European identity loosing attractiveness" (Lilli 1998: 154, translated quotation) ${ }^{32}$. In fact, the situation of the still relatively young political sovereignty becomes particularly precarious within the described forms and hierarchic structure of centre and periphery ${ }^{33}$.

Positive and negative experiences of Europe and related images and identity attitudes are certainly not distributed equally among the population. Internal conflicts grow as cleavages between 'winners' and 'losers' harden. Analogous to social groups, the political parties polarise increasingly along the topic of 'accession to the Union'34. And here the judgements about a 'Europeanisation' of Poland vary. One group of politicians, intellectuals and publicists of the right wing put the so-called 'European cosmopolitanism' in opposition to a 'true' Polish national consciousness, other representatives of the political and intellectual spectrum try to underline the binding of the Polish national consciousness to the idea of Europe (Holzer 1996: 97).

Hence, the cleavage that divides the Polish society did not only develop along the line of 'elites versus masses', although some correlation with the degree of education certainly exists. The topic won increasingly public interest and importance as the date of accession approached. Correspondingly the tone of discussion became sharper. This was especially the case in Poland ${ }^{35}$ : "We are not going to Brussels begging on our knees' expressed Ryszard Czarnecki, the chairman of the state-committee for European integration of that time, before the negotiations for accessing were opened officially in the end of March 1998. And the chiefnegotiator, Jan Kolakowski, underlined that Poland will not allow to be pushed into the role of the poor cousin" (Juchler 1999: 486, translated quotation). ${ }^{36}$

Yet the motivations for, refusing the EU are diverse. Nationally oriented persons "originate either from right-wing circles (among them also national-conservative groups of Polish Catholicism), where above all the dangers for the Polish culture are underlined, or from leftwing circles, who appeal to the dangers for the Polish economy" (Holzer 1996: 97, translated quotation). 
Discussions about the creation of a supranational 'State of Europe' usually provoke negative reactions. An extreme right-wing view - that is possibly not able to win majorities in this form, but comes close to the core of general worries - is that no new restrictions on Polish sovereignty should be allowed. For this reason, it considered accession to the EU as being out of question. Such positions frequently constructed a remarkable equalisation of European Union and communism and named both as 'people's prisons' (Strobel 2001: 266f.). ${ }^{37}$

Strobel (2001: 277, translated quotation) assumes that "the rightist changed fundamentally the initially positive attitude of the society regarding the EU and the opening towards the West". Although it is not possible to quantify this influence, it certainly goes beyond being marginal to a considerable degree (see Strobel 2001: 280). This is also reflected by the results of public opinion polls regarding the accession to the European Union. While in $199679 \%$ of the representative random sample supported accession to the EU, in November 2001 it was only 49\%. In 1996, 7\% were explicitly against the accession, while in November 2001 this share was more than $30 \%$ (Mildenberger 2002: 3 ). ${ }^{38}$

The represented attitudes and ideas offer a basis for a nationally inspired counter-identity that causes problems for the 'project united Europe' particularly when it instrumentalises an antagonism between the nation and the EU. The spectrum of opinions is broad and highly diversified. But certain structures and ways of acting risk the consolidation of problems which can become more complicated as long as they are neither understood nor solved.

\subsubsection{Attempts of Compensation on the Basis of Alternative Identity-aspects}

For the self image of a group it is of crucial importance to be more successful than others, when it comes to shared social values. If this is not the case, other dimensions of values can experience a revaluation in order to re-establish a balance. In Europe, certain economic values for example are generally highly estimated and often correlate with the distribution of political power (Lilli 1998: 144).

In the Polish case this is expressed through the question 'does the country risk its own identity by 'returning to Europe'?' (Bingen 1992: 62). If Europe is equated with relativism, atheism, drugs, pornography, abortion, divorce, homosexuality - in a word, Babylon, Sodom and Gomorrha altogether (Michnik 1993; Buchowski 1997: 34f.) the conclusion can be drawn that states that Poland is 'the real Europe' and that 'returning to Europe' is the task of Western Europe and its deteriorated morals (Bingen 1992: 74). Partly, the idea of a Polish mission which is well known from the historic images of the Polish nation and its relation to Europe is taken up and centres around the idea of morally influencing and healing the sick Europe (Strobel 2001: 266).

\section{Conclusions}

On one side it is possible agree to Holzer, who assumes that the Polish fears and hopes are more or less comparable to the ones of the old member states. However, he modifies that for Poland, an insecurity about its role and the related positions within the EU context, remain specific (Holzer 1996: 103f.). It is obviously not enough to restrict relations within the European Union to the acceptance of formal aspects and rules, particularly if the process of European integration should not lose its basis because of inadequate specific and diffuse support. However, the structure which on several levels is perceived as being systematically asymmetrical and interpreted as hierarchical means a risk for the common project. Although interests in this project are undeniable on both sides, the potential consequences of the described difficulties are serious, even more as there are already close interdependencies between Western and East Central Europe.

Despite the complex structure of relations, how can the multidimensional national identities on the European level or regional identities on a German level favour a shared foundation of 
new types of collective identities? The following arguments shall help answering this question. First of all, the connection of diffuse and specific support has to be considered. It seems that in the long run diffuse support cannot remain stable without specific support. This means, that an output increase - on the side of the West in Germany as well as in Europe could contribute to avoiding the successful stabilisation of particular and exclusive identities. This is probably most realistic in fields of shared interests. But it has to be kept in mind that such decisions mainly depend on definitions and interpretations.

Two aspects have to be differentiated: while on an economic level a growing material and interests-related output probably would be assessed positively by the weaker partner, politically shared decisions made by equal partners would need to be more extensive. Partly, these two aspects stand in a substitutive relation and with both the West can express loyalty and solidarity.

In the long run the importance of power and policy related questions grow, because it implies the problem of national sovereignty, which is especially precarious for East Central Europe. Only in this way can positions be met which demand either complete sovereignty of the nation or an equal position within the all European context (Holzer 1996: 101). To a lower degree but structurally comparable, people in East Germany are concerned about possibilities of political influence. In both cases, in order to support structural change it is necessary that the same rules become valid for all players as soon as possible.

Only on these grounds can the image of a legitimate relationship be set up or stabilized respectively. This has to allow independent acting according to the special conditions and logics of life in a periphery (Woderich 1996: 96) because it is highly improbable that the economic asymmetry will be overcome within the foreseeable future.

For establishing legitimacy, loyalty and solidarity in both cases a common framework of values, norms and mutual understanding is necessary. The simple logic of a quid pro quo exchange is not enough (Bertelsmann Foundation 2001: 37). This would favour European identities which were less dependent on economic trends and would, also correspond with the explained East Central European type of identification structure. In this sense two aspects are of crucial importance: firstly, the idea of a nameable, distinguishable community with socalled 'pre-political' and past-related elements is necessary as well as, secondly, political and mainly future-oriented aspects.

In this context, neither a homogenised 'EU-society', nor a German equivalent with a uniform and 'obligatory' collective European identity, can be perceived as ideal. Rather, a common political and socio-economic space of communication would have to be established. Its basis has to be sufficiently stable to avoid settlements of conflicts. In this way, the developing communicative space could become the basis of a community of interpretation, which, again, could be functional for the development of new forms of identity (Gephart 1999: 167).

Coming to these decisions it is necessary to make both sides aware of the importance of their respective common project and of possible consequences - especially, because of already very far-reaching interdependencies. This, again, concerns the level of 'concrete' interests. If, however, the East European countries remain within the described multidimensional periphery, considerations of the known structural problems and second-rate 'solutions' will continue. In addition, it has to be taken into account that the development of nationalism can be influenced considerably by the logics of relations between centre and periphery (Jacyno 1994: 66). This does not only mean that shaping a common space becomes more and more difficult, but that substantial parts of responsibility for this development will have to be taken by the respective Western regions. 


\section{Notes}

1 A more detailed discussion of the two terms and potential additional categories can be found in Westle 1999.

${ }^{2}$ In the German case these are the regions East- and West-Germany and European case the different new and old member states.

${ }^{3}$ The decision for this level of analysis is decisive. Easton's understanding obviously includes this interpretation: "The members of a political system who are participating in a common political community may well have different cultures and traditions or they may be entirely separate nationalities" (Easton 1965: 177).

4 Such general differentiations have the advantage to abstract from concrete contents. Therefore, several aspects can be subsumed which might base on perception mainly.

${ }^{5}$ This is also a differentiation from Offe, who developed the idea of a 'dilemma of simultaneity (Offe 1991).

${ }^{6}$ In $198975 \%$ (83\%) of citizens of the European Community agreed to the statement that Poland and Hungary shall receive support of the Community for the development of economic cooperation, 74\% plead for a membership of the East Central European countries when democracy has been installed (Commission of the European Communities 1989). On the other hand, in 1990 98\% of the East Central Europeans agreed with the idea of joining the EC within 10 years (Commission of the European Communities 1990b). In the German-German case in spring 1990 a unification found support of nearly $80 \%$ of the FRG-citizens and of $90 \%$ of the GDR-citizens (Commission of the European Communities 1990a).

7 The term 'collective identity' is defined very varyingly. I understand it as an emotional feeling or consciousness of individuals of belonging to a certain collective unity or social 'lifecommunity', which is characterised distinctively by specific features - like culture, language, history, possibly also religion and race - and therefore distinguishes itself from other collectives (Hillmann 1994: 422). It is important that the individual is chosen as a startingpoint. Additionally, the multidimensionality of the term (next to conscious perceptions of contingencies we find 'naturally understood' aspects like ethnos) and its flexibility (not all elements have to occur at the same time or equally) are relevant.

${ }^{8}$ In $199062 \%$ of the Czechoslovaks, $67 \%$ of the Hungarians and $77 \%$ of the Poles expressed their distrust of Russia (Commission of the European Communities 1990b). In February 2002 nearly $60 \%$ of the interviewed Poles answered 'yes' and only about $20 \%$ 'no' to the question „Will Russia in the next future (5 to 10 years) try to regain influence in our part of Europe or not?" (CBOS 2002a).

${ }^{9}$ Today, on average only $52 \%$ of East Central Europeans view the Union positively, $18 \%$ have a negative picture. Nearly one half worries about the integration of the EU ( $45 \%$ in the Czech Republic, 40\% in Poland, 39\% in Hungary) (Commission of the European Communities 2002b). A similar picture can be observed in Eastern Germany: in 1998 60\% of the Eastern Germans (and 33\% of the Western Germans), expressed that there was reason for being disappointed because of the course of the unification (Noelle-Neumann/Köcher 2002: 499).

${ }^{10}$ In the East wages at the end of 2001 were on average $91,5 \%$ of the Western ones. The difference is even bigger if additional benefits and differing working hours (plus 1.7 hours in the East) are considered as well (Ministry for Labour and Social Order 2001). At the same time $87 \%$ of the East Germans claim equality in wages (Noelle-Neumann/Köcher 2002: 504).

11 This will continue for 7 years: 5 years as a fixed period and afterwards another two years of interim solution.

12 The EU refuses direct payments of the amount of old member-states for new memberstates. Instead, in 2004 the payments start on a level of $25 \%$ and shall become equal in 2013 (arguments can be found in: Commission of the European Communities 2002a).

${ }^{13}$ The question, if the West should show more readiness to sacrifice, in 1998 was affirmed by only $29.4 \%$ of the West-Germans (East-Germans: $67.7 \%$ ), in 1991 , however, it still was $51.1 \%$ of the interviewed persons. In the East, on the other hand, the approval to the opinion, that the East has to be more patient, decreased rapidly: while in $199457.8 \%$ of the East-Germans agreed, in 1998 it was only 39.1\% (West-Germans: 87.2\%) (Allbus 1998). Asked if they have the impression that the West-Germans want to contribute to the development of Eastern Germany, in 2000 47\% of the East-Germans disagreed (21\%,yes') (Noelle-Neumann/Köcher 2002: 502). 
${ }^{14}$ In $200257 \%$ of East-Germans felt like, second class-citizens' (36\% did not) (Noelle-Neumann 2002: 521). All in all, the huge discrepancy between the answers to the numerous questions show a considerably different perception in the East and the West. Also, in 2000 only $51 \%$ of the East-Germans believed that the integration will be successful (61\% of the West-Germans) (Noelle-Neumann/Köcher 2002: 497). 59\% of the East-Germans in 2000 thought that differences and $13 \%$ stated that common features with the West predominate (West: $28 \%$ common features, 35\% differences) (Noelle-Neumann/Köcher 2002: 522).

15 Therefore, political forms of 'desired deviance' are observable, for example the relatively important position of the socialist (formerly communist) party in the Eastern parts of Germany. Their inclusion in regional governments is seen positively by only $19 \%$ of the WestGermans, compared to $47 \%$ of the East-Germans (Allensbach 2002).

${ }^{16}$ Significantly less East-Germans mentioned institutions when asked about what they felt pride in their country. In 1996 52.9\% of the West-Germans cited the Basic Law compared to $24.1 \%$ of the East-Germans (Allbus 1998). Also, in $200061 \%$ of the West-Germans believed that the problems of the country can be solved with democracy, while only $33 \%$ of the EastGermans did so (Noelle-Neumann/Köcher 2000).

${ }^{17}$ This applies as a principle but with no doubt the degree of exclusion is important.

${ }_{18}$ 'Obstinate' is a translation of the German word 'eigensinnig'. Literally this means 'with its/one's own sense'.

${ }^{19}$ This is proved by attitudes concerning the statement "What is to become of the people in East-Germany fundamentally depends on what they are ready to achieve" (in 1998 West: 78.9\%, East: 34.7\%) (Allbus 1998, see footnote 13).

${ }^{20}$ One sign is the Western German tendency to perceive more 'normalization' and 'mutual assimilation' on the one hand and much less differences on the other compared to the East (e.g. Noelle-Neumann/Köcher 2002: 523).

${ }^{21}$ In 2000 in the West only 24\% saw themselves as 'West-Germans' and 70\% as 'Germans', while in the East 53\% perceived themselves primarily as 'East-Germans' (compared to $41 \%$ 'Germans') (Noelle-Neumann 2002: 525).

22 This work was oriented toward the political ideas of the Enlightenment. The constitution delegated the 'sovereignty of the nation' to the parliament. The parliament was transformed to a strong and united agency of legislation by laying down the principle of majority. Consequently it followed the principle of separation of powers and trusted the government with the executive power. This government was responsible towards the parliament. Hence a written constitutional law has been created which was placed over singular influences. This has to be named ,modern'. But simultaneously the principle of the corporative state has not been touched. The political nation, that appeared as the holder of sovereignty, was not the complete people but the traditional, nobility-nation'. This instead consisted of a few rich magnate's families and an exceedingly numerous ,middle'- and ,small-nobility'. The 'nobilitynation' nevertheless claimed for itself to have realised the modern, founding on principles of ,natural-right' constitution with peoples' sovereignty and national freedom (Stollberg-Rilinger 2000: 244f.).

${ }^{23}$ This ethos was able to support the communication with other suppressed peoples (but it didn't necessarily do so). Examples for this are in the $19^{\text {th }}$ century internationalism of the independence movements as well as a specific Polish 'messianism', which plead for the struggle 'for your and for our freedom' (Holzer 1991: 394).

${ }^{24}$ Obviously, in the context of religion as well as ideology of the Enlightenment the bond with (Western) Europe historically quite constantly has been connected with a certain mysticism, which supported the idea of a 'quasi-natural unity'.

25 In 1772, Prussia, Austria and Russia were dividing parts of Poland among themselves. In 1791 Prussia and Russia did the same, 1795 Prussia and Austria, whereby as a consequence of the last division Poland disappeared completely off the map.

${ }^{26}$ This turn is interpreted by several East Central European authors primarily as an externally dominated aspect. Krasnodebski for example writes: "The Poles have been increasingly considered a big ethnic group without the right of political sovereignty. They changed from being a nation to being an ethny - though this was on no account a self-chosen way" (Krasnodebski 1995, 246, translated quotation). Such a judgement of the history, however, implies the risk of overly extensive externalisation of responsibility for structural changes - 
with a potentially problematic impact on the present-day situation. But: Under such circumstances an exclusive self-definition is certainly more probable, but not inevitable.

27 Indeed, Poland achieved national sovereignty in 1918, but it didn't subsist in a democratic form until the marching in of the Nazi-Germans in 1939. In 1926 Józef Piłsudski with the support of the military triggered a coup d'état, established an only seemingly democratic, authoritarian regime and governed as a dictator until his death in 1935.

${ }^{28}$ This is one of the most problematic arenas within the EU - also independently of the enlargement.

${ }^{29}$ In accordance Polish farmers judge the relations with the EU most critically: $79 \%$ believe that mostly the EU has had advantages so far. $82 \%$ of them expect future disadvantages of the integration (CBOS 2002c: $5 \mathrm{ff}$.). $56 \%$ of the Poles (and $86 \%$ of the Polish farmers) agreed that the country should insist on the whole amount of agrarian subventions, even if the negotiations would fail and Poland would have to remain outside the EU (CBOS 2002b).

${ }^{30}$ This certainly is also a well-known feeling of Western populations in this context.

31 Additionally this meets a certain disillusionment on the side of the West: "The initial euphoria in the East of Europe changed to rage and anxiety, in the centre to frustration and in the West to nervosity and impatience" (Glotz 1992, 51, translated quotation).

${ }^{32}$ A famous Polish intellectual (with Solidarnosc-roots), Adam Michnik, stated, "that the term 'European' in Poland sounds more and more like an invective and is used in political debates as a synonym for 'cosmopolitan who despises his own nation' (cited after Krasnodebski 1993: 267 , translated quotation).

${ }^{33}$ Related to this question Srubar mentions "the fear of the East Central European countries that under these conditions they might become a periphery of the EU (...) - perhaps because of their growing dependence on the compensation-payments they could find themselves in the role of receivers of social security at the edge of the Union" (Srubar 1995: 684, translated quotation).

${ }^{34}$ Mildenberger states that the topic of Europe in politics "at the latest since the elections in September 2001 (...) became subject of a polarized and polemic debate between government and opposition, but also within the Polish society" (Mildenberger 2002: 6, translated quotation).

${ }_{35}$ But also in Hungary and the Czech Republic such comments get louder. Vaclav Klaus published on his homepage (9.5.2001, www.klaus.cz) the following: "As a citizen of a nonmember state of the EU I have to accept that - unfortunately - membership respectively nonmembership became a factor of differentiation that shows, which country is a normal, according to the standard (or standardised), adult, obedient country and which one isn't. (...) For this reason we have no other choice but endeavouring ourselves with maximal intensity to a possibly fast membership - and that notwithstanding our attitudes toward the presentday model of European unification and its hidden ideology. (...) However, I'm convinced that the member states are interested in keeping the status quo as long as possible. Let's disregard rhetorics, the non-member states for them are fully accessible and they have the full possibility to realise their comparative advantages in a one-sided and for them painless way".

${ }^{36}$ At this point, the problematic combination of political and economic aspects becomes evident, because in the context of the accessions a close correlation between some loss of sovereignty and material compensation exists: "the EU is already sold to the Central European public (...) as an exchange in which dissolving sovereignties and clear subordination to the center are compensated with invitations to a cash window in Brussels" (Tamás 2001: 6).

37 Strobel writes further: "Andrzej Lepper, chairman of the self-help-organisation, Samoobrona' (i.e. self-defence, A.S.K.), that is popular among peasants, called the EU plastically and deterrently a 'new kolkhos'. The differences to the status quo ante were only that the former one had his place of residence in Moscow, whereas the current one were directed from Brussels" (Strobel 2001: 278, translated quotation).

${ }^{38}$ This corresponds with results from the whole East Central European region: $45 \%$ in the Czech Republic, 40\% in Poland and 39\% in Hungary worry about the EU-Integration in general (Kommission der Europäischen Gemeinschaften 2002). 


\section{References}

Allbus (1998). Online Codebuch. www.gesis.org/Datenservice/allbus/Guide.htm

Allensbach (ed.) (2002). Rot-rote Koalition in Berlin stößt in der Bevölkerung auf Ablehnung. Allenbacher Berichte Nr. 3, www.ifd-allensbach.de

Bafoil, F. (1995). 'Systemumbruch in Ostdeutschland und Polen zwischen außengesteuerter Integration und endogener Systemveränderung,' in Wollmann, Hellmut/ Wiesenthal, Helmut/ Bönker, Frank (eds.) Transformation sozialistischer Gesellschaften: Am Ende des Anfangs. Opladen: Westdeutscher Verlag, pp. 597-608.

Bergem, Wolfgang (1999). 'Kultur als Identitätsgenerator in ostdeutschen Regionen. Zum Verhältnis von Integration und Differenz im vereinten Deutschland',in Reese-Schäfer, Walter (ed.) Identität und Interesse. Der Diskurs der Identitätsforschung. Opladen: Leske + Budrich, pp. 181-205.

Bertelsmann Foundation and Center for Applied Policy Research (ed.) (2001). Thinking Enlarged. The Accession Countries and the Future of the European Union. Villa Faber Group on the Future of the EU. http://europa.eu.int/futurum/documents/other/oth001101ter en.pdf

Bingen, Dieter (1992). 'Demokratisierung und Nationalismus in Polen', in Mommsen, Margareta (ed.) Nationalismus in Osteuropa. Gefahrvolle Wege in die Demokratie. München: Beck, pp. 47-76.

Buchowski, Michal (1997). 'Neue kollektive Identitäten in Mittel- und Osteuropa. Zur Dialektik europäischer Identitäten', WeltTrends, 15, pp. 25-37.

CBOS (2002a). Opinions on the European Commission's negotiation position on payments for farmers. www.cbos.com.pl/ENGLISH/OPINIA/2002/02 2002.pdf

CBOS (2002b). About negotiations with the $E U$ on agriculture. www.cbos.com.pl/ENGLISH/OPINIA/2002/05 2002.pdf

CBOS (2002c). Opinie o integracji Polski z Unia Europejska. BS/59. www.cbos.com.pl/cbos pl.htm, (wyniki, rok 2002) (accessed 31.8.2002).

Commission of the European Communities (ed.) (1989). Eurobarometer Nr. 32, December.

Commission of the European Communities (ed.) (1990a). Eurobarometer Nr. 33, June.

Commission of the European Communities (ed.) (1990b). Eurobarometer Nr. 34, December.

Commission of the European Communities (ed.) (2001). Eurobarometer Nr. 55, Spring.

Commission of the European Communities (ed.) (2002a). Erweiterung und Landwirtschaft: Die erfolgreiche Integration der neuen Mitgliedsstaaten in die GAP. Diskussionspapier, Brüssel. http://auswaertiges-amt.de/www/de/infoservice/download/pdf/eu/landwirtschaft.pdf

Commission of the European Communities (ed.) (2002b). Eurobarometer der Kandidatenländer 2001, March.

Ders. (2000). 'Allgegenwärtig, ungreifbar. Zur Entdeckung ostdeutscher Identitätsbildungen in Befunden der Umfrageforschung', Berliner Debatte Initial 11/3, pp. 103-116.

Easton, David (1965). A Framework of Political Analysis. New York: Prentice-Hall. 
Gephart, Werner (1999). 'Zur sozialen Konstruktion europäischer Identität. Symbolische Defizite und europäische Realitäten', in Gephart, Werner/ Saurwein, Karl-Heinz (ed.) Gebrochene Identitäten. Opladen: Leske + Budrich, pp. 143-168.

Hillmann, Karl-Heinz (1994). Wörterbuch der Soziologie. Stuttgart: Kröner.

Holzer, Jerzy (1991). 'Die politische Kultur Polens: Geschichte und Gegenwart', Zeitschrift für Politik 4 (38), pp. 392-405.

Holzer, Jerzy (1996). 'Polen in Europa: Zentrum oder Peripherie?', in Bundeszentrale für politische Bildung (ed.) Europabilder in Mittel- und Osteuropa. Bonn, pp. 87-104.

Jacyno, Malgorzata (1994). 'Center and Periphery - Continuity and Change', in Jawlowska, Aldona/ Kempny, Marian (ed.) Cultural Dilemmas of Post-Communist Societies. Warschau: IFiS, pp. 59-68.

Jaworski, Rudolf (1992). 'Leben mit Geschichte', in Kobylinska, Ewa/ Lawaty, Andreas/ Stephan, Rüdiger (ed.) Deutsche und Polen. München/ Zürich: Piper, pp. 15-22.

Klunkert, Susanne (1996). 'Europabilder in Mittel- und Osteuropa: Vom Wunschbild zum Abbild der europapolitischen Realität', in Bundeszentrale für politische Bildung (ed.) Europabilder in Mittel- und Osteuropa. Bonn: Europa-Union-Verlag, pp. 231-247.

Krasnodebski, Zdislaw (1993). 'Polens Rückkehr nach Europa', in Schäfers, Bernhard (ed.) Lebensverhältnisse und soziale Konflikte im neuen Europa. 26. Dt. Soziologentag. Frankfurt a.M.: Campus, pp. 267-272.

Krasnodebski, Zdislaw (1999). 'Modernisierung und Zivilisierung in Polen. Tradition und Gegenwart', in Krasnodebski, Zdislaw/ Städtke, Klaus/ Garsztecki, Stefan (ed.) Kulturelle Identität und sozialer Wandel in Osteuropa: Das Beispiel Polen. Hamburg: Krämer, pp. 69-108.

Leipold, Helmut (2000). 'Offene Ordnungsprobleme einer Osterweiterung der EU', in Paraskewopoulos, Spiridon (ed.) (2000) Die Osterweiterung der Europäischen Union. Chancen und Perspektiven. Berlin: Duncker u. Humblot, pp. 41-60.

Lilli, Waldemar (1998). 'Europäische Identität: Chancen und Risiken ihrer Verwirklichung aus einer sozialpsychologischen Grundlagenperspektive', in König, Thomas (ed.) Mannheimer Jahrbuch für europäische Sozialforschung. Band 3: Europa der Bürger? Frankfurt a.M.: Campus, pp. 139-158.

Löwenthal, Richard (1985). 'Die Gemeinsamkeiten des geteilten Europa', in Weidenfeld, Werner (ed.) Die Identität Europas. München/ Wien: Bundeszentrale für politische Bildung, pp. 43-65.

Mildenberger, Markus (2002). 'Die Europadebatte in Politik und Öffentlichkeit der ostmitteleuropäischen EU-Kandidatenländer', Aus Politik und Zeitgeschichte B 1-2, pp. 3-10.

Ministry of labour and social order (ed.) (2001). Tarifvertragliche Arbeitsbedingungen im Jahr 2001. http://www.bma.de/data/64952CFADCC14089B09E7D833E8E36F3.0.pdf

Noelle-Neumann, Elisabeth (2000). 'Die Deutschen haben die Probe als Nation bestanden. Die Wiedervereinigung ist aber noch nicht abgeschlossen', FAZ Nr.225 vom 27.9.2000, p. 5.

Noelle-Neumann, Elisabeth/ Köcher, Renate (2002). Allensbacher Jahrbuch der Demoskopie 1998-2002. München: Saur.

Offe, Claus (1991). 'Das Dilemma der Gleichzeitigkeit', Merkur 505/45, pp. 278-292. 
Strobel, Georg W. (2001). 'Das andere Polen. Struktur und Selbstverständnis der rechten und rechtsextremen Kräfte in der polnischen Politik', Osteuropa 3, pp. 259-280.

Tamás, Pál (2001). 'Public Perceptions of the Europeanization and Sovereignty Debates in the Enlargement Countries', in Tamás, Pál / Becker, Ulrike (ed.) Social Science in Eastern Europe. The Countries of Central and Eastern Europe and the EU: Attitudes and Perceptions. IZ/GESIS Newsletter, Special Edition, pp. 5-14.

www.social-science-

gesis.de/en/publications/magazines/newsletter_eastern_europe/nl01s/nl sh_2001.pdf

Tatur, Melanie (1994). 'Identität und Integration - der polnische Diskurs zu Beginn der neunziger Jahre', in Forschungsstelle Osteuropa an der Universität Bremen (ed.) Kollektive Identitäten in Ostmitteleuropa: Polen und die Tschechoslowakei. Bremen: Edition Temmen, pp. 15-72.

Westle, Bettina (1999). Kollektive Identität im vereinten Deutschland. Nation und Demokratie in der Wahrnehmung der Deutschen. Opladen: Leske + Budrich.

Woderich, Rudolf (1996). 'Peripherienbildung und kulturelle Identität', in: Kollmorgen, Raj/ Reißig, Rolf/ Weiß, Johannes (ed.) Sozialer Wandel und Akteure in Ostdeutschland. Opladen: Leske + Budrich, pp. 81-99. 